\title{
Toxic effects of increased sediment nutrient and organic matter loading on the seagrass Zostera noltii
}

Laura L Govers, Jan HF de Brouwer, Wouter Suykerbuyk, Tjeerd J Bouma, Leon PM Lamers, Alfons JP Smolders, Marieke M van Katwijk (2014)

Aquatic Toxicology 155: 253-260

\section{Abstract}

As a result of anthropogenic disturbances and natural stressors, seagrass beds are often patchy and heterogeneous. The effects of high loads of nutrients and organic matter in patch development and expansion in heterogeneous seagrass beds have, however, poorly been studied. We experimentally assessed the in situ effects of sediment quality on seagrass (Zostera noltii) patch dynamics by studying patch $(0.35$ $\mathrm{m}$ diameter) development and expansion for 4 sediment treatments: control, nutrient addition (NPK), organic matter addition (OM) and a combination (NPK+OM). OM addition strongly increased porewater sulfide concentrations whereas NPK increased porewater ammonium, nitrate and phosphate concentrations. As high nitrate concentrations suppressed sulfide production in NPK+OM, this treatment was biogeochemically comparable to NPK. Sulfide and ammonium concentrations differed within treatments, but over a 77 days period, seagrass patch survival and expansion were impaired by all additions compared to the control treatment. Expansion decreased at porewater ammonium concentrations $>2000 \mu \mathrm{mol} \mathrm{L}^{-1}$. Mother patch biomass was not affected by high porewater ammonium concentrations as a result of its detoxification by higher seagrass densities. Sulfide 
concentrations $>1000 \mu \mathrm{mol} \mathrm{L}{ }^{-1}$ were toxic to both patch expansion and mother patch. We conclude that patch survival and expansion are constrained at high loads of nutrients or organic matter as a result of porewater ammonium or sulfide toxicity.

\section{Introduction}

Seagrass beds are among the most productive and biodiverse ecosystems in the world (Hemminga and Duarte, 2000; Orth et al., 2006). Unfortunately, they are severely threatened by increasing human activities in coastal areas (Orth et al., 2006; Waycott et al., 2009). The most imminent problems for seagrass meadows are related to the large-scale eutrophication of coastal waters (Burkholder et al., 2007; Duarte, 2002; Orth et al., 2006; Waycott et al., 2009). Eutrophication results in light limitation for submerged species, as it promotes the growth of epiphytes and phytoplankton, but may also directly affect seagrass vitality through ammonium toxicity (Brun et al., 2002; Van der Heide et al., 2008; van Katwijk et al., 1997). High ammonium levels are known to be able to disrupt the uptake of essential cations such as potassium by higher plants, affect their $\mathrm{pH}$ regulation, and decrease overall growth rates (Britto and Kronzucker, 2002).

In addition, eutrophication related to land use change (including deforestation) often increases the organic matter input into coastal sediments, thereby not only increasing ammonium levels even further, but also fueling the production of sulfide (Burkholder et al., 2007; Van der Heide, 2009). Sulfide is a strongly phytotoxic compound, as it blocks the activity of cytochrome oxidase and other metal 
containing enzymes (Lamers et al., 2013). It is formed in anaerobic sediments rich in organic matter, where sulfate is used as an alternative terminal electron acceptor during the microbial breakdown of organic matter (Gray and Elliott, 2009; Holmer and Nielsen, 1997). Sulfide toxicity, due to the build-up of sulfides in the sediment, may lead to massive seagrass die-offs (Borum et al., 2005; Carlson et al., 1994; Terrados et al., 1999).

The deterioration of habitat quality, including eutrophication and sulfide toxicity, has led to the complete disappearance of seagrass beds in some regions (Borum et al., 2005; Burkholder et al., 2007). In other areas, it has created heterogeneous, patchy seagrass landscapes (Duarte and Sand-Jensen, 1990; Frederiksen, 2004; Pasqualini et al., 1999) which reflect processes of recovery from disturbances (Brun et al., 2003a; Duarte and Sand-Jensen, 1990; Pickett and White, 1985). A patch, defined as "a surface area that differs from its surrounding in nature or appearance" (Turner et al., 2001), may result from both sexual and asexual colonization (Bostrom et al., 2006; Duarte and Sand-Jensen, 1990), and from habitat fragmentation of seagrass beds. Patches expand through shoot expansion, mainly through horizontal elongation of rhizomes at the patch edges (Duarte et al., 2006a; Marba and Duarte, 1998; Olesen and Sand-Jensen, 1994; Vermaat, 2009). Their shoot densities increase exponentially (self-accelerating) with increasing patch age and size (Bostrom et al., 2006; Sintes et al., 2005; Vermaat, 2009; Vidondo et al., 1997).

Most studies have tended to focus on large-scale processes (Bell et al., 1999) in seagrass beds, rather than on ubiquitous but small-scale dynamics. Studies 
describing seagrass patch dynamics (Almela et al., 2008; Brun et al., 2003b; Campbell and Paling, 2003; Di Carlo and Kenworthy, 2008; Duarte and Sand-Jensen, 1990) focused on plant physiology rather than on the impact of environmental characteristics including local sediment biogeochemistry. Eutrophication and sulfide toxicity, two environmental stressors of seagrass meadows that have rapidly become common at a global scale, may not only contribute to the formation of patches, but can also be expected to affect patch expansion itself. As patchy seagrass meadows are expected to be more vulnerable to stressors than homogeneous fields due to their lower regrowth capacities and the higher impact of hydrodynamics (Bos and van Katwijk, 2007; Duarte and Sand-Jensen, 1990; Olesen and Sand-Jensen, 1994), it is important to know the effects of both important, potentially phytotoxic stressors on seagrass patches. To our knowledge, experimental manipulation of sediment quality to study the effects on seagrass patch expansion has never been carried out before. We therefore assessed the possible toxic effects of changes in biogeochemical sediment quality related to eutrophication (increased levels of nutrients and organic matter) on small-scale seagrass patches, using the fast growing Zostera noltii as a model species.

\section{Materials and Methods}

2.1 Study Area. The experiment was conducted in an intertidal Zostera noltii bed on the mudflats of Viane $\left(51^{\circ} 39^{\prime} \mathrm{N}, 4^{\circ} 01^{\prime} \mathrm{E}\right)$, the Oosterschelde, in the southwestern part of the Netherlands. The Oosterschelde delta has a surface area of $351 \mathrm{~km}^{2}$ and a tidal amplitude of 2.5-3 m (Troost et al., 2009). Mean surface water temperature 
fluctuates between $0-22^{\circ} \mathrm{C}$ annually. Freshwater input into the former estuary has become highly limited after the implementation of major water works in the past, and salinity is generally around 30 (Nienhuis and Smaal, 1994).

Zostera noltii meadows cover around 75 ha of the mudflats in the Oosterschelde, growing mainly in sheltered areas near dikes. At the experimental site, Zostera noltii was growing within 30 meters of a dike, on a compact clay bank with a median grain size (D50) of $130 \mu \mathrm{m}$ and \% organic carbon of $0.72 \%$. At the start of the experiment, the seagrass cover of the meadow was relatively homogeneous (2250 \pm 124 shoots $\mathrm{m}^{-1}$ ) and biogeochemical characteristics of the meadow were also determined (sulfide $=0.31 \pm 0.22, \mathrm{NH}_{4}=13.14 \pm 2.09, \mathrm{NO}_{3}=5.51 \pm 1.44, \mathrm{PO}_{4}=8.95 \pm 0.84, \mu \mathrm{mol}$ $\mathrm{L}^{-1}, \mathrm{n}=21$ ). Experimental seagrass patches, as well as the natural bed, were located on the mudflat at an average height of $54 \mathrm{~cm}$ above Amsterdam Ordnance Datum (NAP), resulting in exposition to the atmosphere for on average 7 hours during each low tide, depending on weather conditions. This intertidal mudflat was flooded and drained with each tidal cycle (semidiurnal).

2.2 Experimental design. Circular Zostera noltii sods of $35 \mathrm{~cm}$ in diameter and $7 \mathrm{~cm}$ depth were carefully collected from a homogeneously covered meadow, and transplanted to a bare stretch of the mudflat between the dike and the seagrass bed nearby. This area is known to be a suitable seagrass habitat, as seagrass was present and vital at this site until it was removed during dike reinforcement works in the previous growing season. The sods were transplanted into circular spots of $105 \mathrm{~cm}$ diameter and $7 \mathrm{~cm}$ depth. Before placing the sods, the different sediment treatments (details next section) were applied on the bare sediment. The sods, 
hereafter referred to as mother patches, were placed in the middle of the treated sediment spots and the remains were filled up with local sediment. Treatments were randomly assigned to the patches, using eight replicates $(n=8)$ per treatment. The experiment was carried out for 77 days, from June till September 2009.

2.3 Sediment treatments: nutrient and organic matter addition. To study the separate and interacting effects of sediment eutrophication, we applied four different biogeochemical treatments: a control treatment (Control), an organic matter treatment (OM), a nutrient treatment (NPK) and a combined treatment of both nutrients and organic matter (NPK+OM). We fertilized NPK and NPK+OM plots with $1.11 \mathrm{~kg} \mathrm{~m}^{-2}$ Osmocote ${ }^{\circledR}$ slow release fertilizer (g:g:g ratio N:P:K 18:9:10) with a longevity of 8-9 months. The fertilizer was distributed evenly beneath the seagrass sods and the surrounding, bare sediment. Loading rates were around $57 \mathrm{mmol} \mathrm{N} \mathrm{m}^{-2}$ day $^{-1}$ and $13 \mathrm{mmol} \mathrm{P} \mathrm{m}^{-2}$ day $^{-1}$ (Christianen et al., 2012; Vanlent et al., 1995).

For the organic matter treatments (OM and NPK $+\mathrm{OM})$, we added $2 \mathrm{~g} \mathrm{~L}^{-1}$ of organic matter ( $1 \mathrm{~g}$ starch $+1 \mathrm{~g}$ cellulose $\mathrm{L}^{-1}$ sediment), which equaled a loading rate of about $157 \mathrm{mmol} \mathrm{C} \mathrm{m}{ }^{-2}$ day $^{-1}$ (for 47 days), under the seagrass sods, which was expected to stimulate sulfide production (Peralta et al., 2003; Ruiz-Halpern et al., 2008). All treatments were applied only once, at the start of the experiment. However, the NPK and NPK+OM treatments appeared to generate biogeochemically similar results, as high nitrate levels suppressed sulfide production. As a result, this unforeseen effect of combined NPK and OM addition did not result in an expected interaction treatment. 
2.4 Data collection in the field. Sediment samples were collected at the start of the experiment for chemical analyses to characterize the local habitat. Patch heights were measured using a RTK-DGPS (Real Time Kinematic Global Positioning System) (Van der Heide et al., 2010a), but did not differ significantly among treatments. During the experiment, sediment porewater samples were collected anaerobically at $\mathrm{t}=0,21,49,77$ days, using $60 \mathrm{~mL}$ vacuumed syringes connected to ceramic soil moisture samplers (Eijkelkamp Agrisearch Equipment, Giesbeek, the Netherlands), which were placed in the top $7 \mathrm{~cm}$ of the sediment. For each experimental patch, two porewater samples were taken, one inside the mother patch and one just outside the patch, but within the sediment treatment area (potential expansion area). Samples were pooled for analysis. Of each anaerobic sample, $10 \mathrm{~mL}$ was used for sulfide analysis on the same day (see below), and $40 \mathrm{~mL}$ was frozen until further chemical analyses. After porewater extraction, shoot numbers within the transplanted patches and shoot numbers of the patch outgrowth (patch expansion) were monitored, by counting all shoots. After 77 days, the experiment was terminated and patch shoot density was determined. The patch expansion area (all seagrass biomass produced outside the $0.35 \mathrm{~m}$ diameter patch) was harvested for all patches and a small core (diameter $0.06 \mathrm{~m}$ ) was taken inside the patch to determine patch biomass. Harvested samples were rinsed and split up into aboveground (leaves and sheath) and belowground (rhizomes and roots) biomass, and dried at $60^{\circ} \mathrm{C}$ until constant weight, and weighed (g DW).

2.5 Analysis of porewater and plant samples. Within 5 hours after sampling, total sulfide concentration in the porewater was measured in a mixture of $50 \%$ sample 
and 50\% Sulfide Anti-Oxidation Buffer (SAOB) (Lamers et al., 1998), using an ionspecific silver-sulfide electrode. Porewater ammonium and ortho-phosphate concentrations were measured colorimetrically (Skalar and Seal autoanalyzer), using ammonium-molybdate and salicylate (Lamers et al., 1998). Nitrate was determined by sulphanilamide, after reduction of nitrate to nitrite in a cadmium column (Wood et al., 1967).

To assess seagrass nutrient status, dry plant material was used to determine $\% \mathrm{C}$ and $\% \mathrm{~N}$ of both leaves and rhizomes, using an elemental analyzer (Type NA 1500 Carlo Erba Thermo Fisher Science, USA), coupled online via an interface (Finnigan Conflo III) to a mass spectrometer (Thermo Finnigan Delta Plus, USA). Total phosphorus in seagrass tissue was measured on an inductively-coupled-plasma emission spectrophotometer (ICP) (Spectroflame, Spectro Inc.), after digestion of dry plant material with nitric acid and $\mathrm{H}_{2} \mathrm{O}_{2}$ (Smolders et al., 2006). Sediment grain size distribution was determined on dried and sieved ( $1 \mathrm{~mm}$ mesh size) samples by laser diffraction on a Malvern (Master 2000) particle size analyzer.

2.6 Statistical analysis. Normal distribution of the data was tested on the residuals, and negatively skewed data were transformed using the square root of the maximum of $x$ minus $x$ (Field, 2005) to meet assumptions of the ANOVAs (Table 1). Biomass and elemental composition were analyzed by 2-way ANOVAs to assess the effects of NPK and OM, with a 95\% confidence interval We used R 3.01 to perform 2way ANOVAs. Porewater nutrient and sulfide data were tested using 3-way repeated measure ANOVAs, to analyze the effects of time $\left(t_{0}, t_{21}, t_{49}, t_{77}\right)$, NPK (+/-) and OM (+/-) (Table 2). We used the Greenhouse-Geisser correction when sphericity 
assumptions were violated. PASW-SPSS 18.0 was used for repeated measures ANOVAs. Exponential regressions were tested with linear models after log transformation the variables on the $\mathrm{Y}$-axis (biomass mother patch and expansion) and untransformed variables on the $\mathrm{X}$-axis (sulfide and ammonium). For sulfidebiomass relationships, only values from the control and OM treatments were taken into account, and for the ammonium-biomass relationships, only results from the control, NPK and NPK+OM treatments. This separate testing of treatments was done to distinguish between the effects of high porewater sulfide or high ammonium, which could each result in a low biomass. Outliers were detected with Dixon's Q-test and removed from the data (Dean and Dixon, 1951).

\section{Results}

3.1 Porewater results. Both the NPK and OM treatment successfully altered biogeochemical sediment characteristics, as expected (Fig. 1). OM addition resulted in significantly elevated porewater sulfide levels (Fig. 1a) up to concentrations of $3000 \mu \mathrm{mol} \mathrm{L} \mathrm{L}^{-1}$ in the OM treatment (repeated measures ANOVA, $\mathrm{F}(1.4)=6.05, P=$ 0.007). In contrast, porewater sulfide levels did not increase in the NPK+OM treatment. High amounts of nitrate were released in both NPK treatments, and sulfide production was almost completely suppressed in the NPK + OM treatment $(F(1.3)=5.88, P=0.007)$, because nitrate is a thermodynamically more favorable electron acceptor than sulfate (Lucassen et al., 2004). The NPK+OM treatment therefore resulted in biogeochemical properties, which were similar to the NPK treatment. The NPK treatment significantly decreased porewater sulfide 
concentrations relative to both the control and OM treatment (Fig. 1, Table 2, $\mathrm{F}(7,71), P=0.023)$. Sulfide concentrations peaked at $3340 \mu \mathrm{mol} \mathrm{L^{-1 }}$ on the $8^{\text {th }}$ of August, but declined to $240 \mu \mathrm{mol} \mathrm{L^{-1 }}$ by the $7^{\text {th }}$ of September, suggesting that OM availability had been exhausted after the $8^{\text {th }}$ of August (47 days). Furthermore, NPK addition resulted in significantly (Table 2 ) elevated porewater ammonium $(F(1.8)=$ 5.87, $P=0.004)$, nitrate $(\mathrm{F}(1.5)=4.678, P=0.038)$ and phosphate concentrations $(F(1.7)=5.52, P=0.026)$ (Fig. 1). Porewater ammonium levels in both nutrient treatments exceeded $4000 \mu \mathrm{mol} \mathrm{L}^{-1}$ (a more than 8-fold increase compared to the controls), and nitrate concentrations increased more than 50-fold compared to the controls up to $>2000 \mu \mathrm{mol} \mathrm{L} \mathrm{L}^{-1}$.

3.2 Biomass response. We observed seagrass expansion (seagrass growth outside the 0.35 m diameter patches) in $100 \%$ of the control treatments $(n=8)$. In contrast, $37.5 \%$ of the patches in the OM and the NPK+OM treatments and only $25 \%$ of the transplanted patches in the NPK treatments expanded. Aboveground biomass of the mother patches decreased in all treatments compared to the initial biomass of $43 \mathrm{~g}$ DW $\mathrm{m}^{-2}$, without significant effects of NPK (2-way ANOVA, $\mathrm{F}(1)=2.53, P=0.123$ ) or OM $(F(1)=2.81, P=0.110)$. Shoot densities (shoots $\mathrm{m}^{-2}$ ) in the mother patches decreased by approximately $75 \%$ in all addition treatments, whereas they did not change in time in the control treatment (Table 2, Fig. 3). Belowground biomass of the mother patches increased in the control treatment, from an initial biomass of 31 $\mathrm{g} \mathrm{DW} \mathrm{m} \mathrm{m}^{-2}$ to a biomass of $40 \mathrm{~g} \mathrm{DW} \mathrm{m}^{-2}$ at the end of the experiment. In stark contrast, belowground biomass was reduced by almost $50 \%$ compared to the initial biomass in all other treatments (Table 1, Fig. 2). 
The aboveground biomass of the expansion did not differ among treatments (Table 1). In contrast, both NPK $(F(1)=4.36, P=0.046)$ and $\mathrm{OM}(\mathrm{F}(1)=4.22, P=0.049)$ addition negatively affected total patch aboveground biomass (Fig. 2, Table 1). Even though all patches received standardized treatments, the effects of NPK or OM addition on biomass parameters (mother patch and expansion biomass) showed high variability (Fig. 4), Some patches in the treatments (NPK, NPK+OM, OM) appeared to manifest less ammonium or sulfide stress (Fig. 4) as reflected by higher biomasses in these units. We therefore tested whether this heterogeneity could be explained by differences in the concentrations in sulfide accumulated, and indeed found a very strong correlation between biomass and porewater sulfide concentrations, $\left(R^{2}=0.69, P<0.001\right.$ for mother patch and $R^{2}=0.70, P<0.001$ for patch expansion). Sulfide levels above $1000 \mu \mathrm{mol} \mathrm{\textrm {L } ^ { - 1 }}$ completely prevented expansion of patches (Fig. 4c) and resulted in their complete die-off (Fig. 4a). Some of the patches already suffered from lower sulfide concentrations. Low patch expansion biomass was also strongly related to high porewater ammonium concentrations (Fig. $4 d, R^{2}=0.61, P<0.001$ ), but we did not find effects on mother patch biomass (Fig $4 b, R^{2}=0.20, P>0.05$ ). We observed no patch expansion at ammonium concentrations $>5000 \mu \mathrm{mol} \mathrm{L} \mathrm{L}^{-1}$, but expansion was already strongly decreased by ammonium concentrations around $2000 \mu \mathrm{mol} \mathrm{L}^{-1}$ (Fig. 4d). Contrastingly, some mother patches were able to tolerate ammonium concentrations $>7000 \mu \mathrm{mol} \mathrm{L}{ }^{-1}$. 
3.3 Plant elemental composition. Leaf nitrogen $(\% \mathrm{~N})$ content of the seagrass leaves of the expansion increased by NPK addition (2-way ANOVA, $F(1)=20.56, P<0.001$, Table 3). Leaf phosphorous content, in contrast, was not significantly affected by any treatment. Zostera noltii did not seem to be nutrient limited in our experiment, as average leaf nitrogen (3.8\%) and phosphorous content $(0.9 \%)$ were well above the values for absolute nutrient limitation (Duarte, 1990). Total sulfur content of the leaves (\% S) was $40 \%$ lower in the NPK treatments $(F(1)=37.73, P<0.001$,) than in the Control and OM only (OM) treatment (Table 3. 1. 1\% versus 1.7\%)

\section{Discussion}

Limitations to seagrass patch survival and development have typically been attributed to physical and biological stressors in literature (Sintes et al., 2005; Townsend and Fonseca, 1998). In this study, we show that also biogeochemical toxins, such as high nutrient and sulfide concentrations, can be highly detrimental to seagrass patch survival and expansion. As the high nitrate levels in the NPK treatment strongly decreased (natural) sulfide production in the sediment, interacting effects of sulfide and ammonium toxicity could not be investigated, and we will therefore discuss the effects of both stressors separately.

4.1 Ammonium toxicity. This is the first study that actually shows a causal relationship for porewater ammonium and toxicity effects in seagrass. Previous 
studies mainly focused on the effects of high nitrate or ammonium concentrations in the surface water layer (Burkholder et al., 1992; Christianen et al., 2011; Van der Heide et al., 2008; van Katwijk et al., 1997). In a correlative study (Short, 1983b) already suggested that porewater nitrogen concentrations of $10-100 \mathrm{mmol} \mathrm{m}^{-2}$ were associated with decreasing eelgrass shoot densities. Ammonium concentrations $>25 \mu \mathrm{M}$ in the water column are known to be potentially lethal to Zostera spp. (Brun et al., 2002; Van der Heide et al., 2008; van Katwijk et al., 1997). The porewater ammonium concentrations we found to completely restrict patch expansion, $>2000-4000 \mu \mathrm{mol} \mathrm{L}{ }^{-1}$, are more than a hundred times higher, although negative effects on biomass were already visible at $1000 \mu \mathrm{mol} \mathrm{L} \mathrm{L}^{-1}$. We could therefore consider Zostera noltii a fairly persistent species for soil ammonium toxicity.

The high threshold values we found compared to surface water ammonium experiments indicates that Zostera noltii is much more resistant to sediment eutrophication than to water column eutrophication (Peralta et al., 2003). This is to be expected, as porewater nutrient concentrations are known to be at least ten times higher than ambient water column concentrations (Burkholder et al., 2007; Touchette and Burkholder, 2000). This difference could also be related to a higher affinity of leaves for ammonium as compared to roots (Thursby and Harlin, 1982). Also, sediment $\mathrm{pH}$ is usually lower than water column $\mathrm{pH}$ as a result of higher $\mathrm{CO}_{2}$ concentrations (pH 7.5 vs. 8.2 on average), which might result in lower ammonium uptake rates in the roots (Toetz, 1973). Furthermore, most water column eutrophication experiments were conducted with Zostera marina, and Z. noltii may 
be more resistant to eutrophication of the water column than Z. marina, and vice versa, Z. marina may be less resistant to high porewater ammonium levels.

The negative effects of biogeochemical stressors seemed to be less pronounced for the mother patch than for patch expansion (Fig. 4). This indicates that the lower shoot density and biomass in the expansion area makes the plants more vulnerable to toxicity, because toxicity cannot be alleviated by joint detoxification or by growth dilution (Van der Heide et al., 2010b). Both processes are strongly affected by population density, and result in denser vegetation being better able to cope with toxins and showing higher growth rates (Van der Heide et al., 2010b). This implies that sparse and patchy vegetation can be expected to be more vulnerable to ammonium toxicity than densely vegetated seagrass beds. At the same time, however, sparse patches may collect lower amounts of detritus leading to lower porewater ammonium and sulfide concentrations. Although even small patches of Zostera noltii seem to be persistent to high porewater ammonium, they were not able to expand or grow during these conditions in our experiment.

Another possible effect of direct nutrient toxicity may be an imbalanced carbonnitrogen ratio due to increased carbon demand (Touchette et al., 2003). We did find a slightly significant effect of NPK addition on C:N ratios (11:1 vs. 12:1) in our experiment, which could imply that this treatment may have resulted in a carbonnitrogen imbalance in the plants. 
Our treatments resulted in very high porewater ammonium concentrations (up to $7000 \mu \mathrm{M}$ ), which is probably the result of the sediment properties (clay) at our experimental site. However, such high porewater ammonium concentrations (1000 up to $7000 \mu \mathrm{M}$ ) have been observed before in eutrophic coastal sediments (Fourqurean et al., 1992; Murray et al., 1978; Pages et al., 2012). And the high porewater ammonium concentrations in our experiment enabled us to investigate the effects of this wide range of ammonium concentrations, which has been observed in natural coastal sediments.

4.2 Sulfide toxicity. High sulfide concentrations of the porewater appeared to be another major constraint for seagrass patch expansion. Sulfide is known to be very toxic to seagrasses (Calleja et al., 2007; Koch and Erskine, 2001; Lamers et al., 2013; Marba et al., 2006; Terrados et al., 1999) and Van der Heide et al. (2012) showed a negative effect on Zostera noltii biomass production at porewater sulfide levels $<200$ $\mu \mathrm{mol} \mathrm{L^{-1 }}$. We found similar threshold values in our field experiment and also found that patch expansion was entirely blocked by sulfide concentrations $>1000 \mu \mathrm{mol} \mathrm{L}^{-1}$. At low sulfide levels, seagrass is usually able to cope with sulfide by oxidizing it in the root zone (Holmer and Bondgaard, 2001; Marba et al., 2006; Pedersen et al., 1998). However, if either sulfide levels become too high, as in our experiment, or when seagrass photosynthesis is constrained or biomass too low, sulfide intrudes into the plants (Garcia et al., 2013; Holmer and Kendrick, 2013). It then interferes with the cytochromes in the electron transport chain, resulting in a negative energy balance, which eventually causes seagrass mortality (Erskine and Koch, 2000; Holmer and Bondgaard, 2001). 
Our results showed that lower sulfide stress is reflected in the sulfur content of Zostera noltii leaves and that sulfide intrusion and sulfur storage already takes place at sulfide concentrations $>200 \mu \mathrm{M}$ (control). It is however remarkable that sulfur storage in the leaves of Zostera noltii did not differ between control (ambient sulfide levels) and OM treatments (elevated sulfide levels). This may be due to decreased vitality of the roots in the high-sulfide treatment (OM), which could severely decrease the uptake of sulfur by the roots.

4.3 Effects on patch development. Patch growth is a self-accelerating process, but it is usually slower than the potential growth rates, as physical and biological stressors interfere (Sintes et al., 2005; Townsend and Fonseca, 1998). Our study adds biogeochemical stressors to this process of patch development. We observed patch expansion in the control patches, but when we added biogeochemical stressors, patch growth was severely limited by ammonium or sulfide toxicity.

4.4 Ecological implications. Eutrophication is one of the major causes of seagrass decline worldwide (Duarte, 2002; Orth et al., 2006; Waycott et al., 2009). As it is known to promote high concentrations of ammonium and sulfide in the porewater (Hauxwell et al., 2001; Short, 1983a; Smolders and Roelofs, 1995), both factors represent important biogeochemical stressors and are expected to influence seagrass expansion processes at a global scale. Although the occurrence of patches is a natural phenomenon in seagrass meadows (Duarte et al., 2006a), the level of 
patchiness is strongly increasing as a result of various human activities (Bostrom et al., 2006).

Patches are very dynamic and normally ensure recovery of seagrass meadows (Duarte et al., 2006b). As we seek to preserve these constantly changing systems (preservation paradox; (Pickett and White, 1985)), it is vital to gain a better understanding of the effects of stressors on system dynamics. The present study showed, for the first time, that patch survival and expansion can be severely influenced by common biogeochemical stressors related to eutrophication, i.e. increased ammonium and sulfide levels, which not only led to thinning of the patches but also precluded patch expansion. Density-dependent alleviation of ammonium and sulfide toxicity will decrease due to the thinning, and subsequently accelerate the decline.

\section{Acknowledgements}


We like to acknowledge Marloes Hendriks, Madelon van de Kerk, Nel Govers, Camiel Doorenweerd, Jeroen Veeken, Eric Gerritsen, Bruce Schoelitz, Lucien Hanssen, Steef Hanssen and Jochem Vink, who were indispensable in the field and the laboratory. We are also grateful to Martin Versteeg, for his help in the field, to Jelle Eygensteyn, for his help with chemical analyses, and to Jim de Fouw for statistical advise. We also thank two anonymous reviewers for their contribution to the improvement of the manuscript. Rijkswaterstaat Zeeland and Projectbureau Zeeweringen funded this research. 


\section{References}

Almela, E.D., Marba, N., Alvarez, E., Santiago, R., Martinez, R., Duarte, C.M., 2008. Patch dynamics of the Mediterranean seagrass Posidonia oceanica: Implications for recolonisation process. Aquatic Botany 89, 397-403.

Bell, S.S., Robbins, B.D., Jensen, S.L., 1999. Gap Dynamics in a Seagrass Landscape. Ecosystems 2, 493-504.

Borum, J., Pedersen, O., Greve, T.M., Frankovich, T.A., Zieman, J.C., Fourqurean, J.W., Madden, C.J., 2005. The potential role of plant oxygen and sulphide dynamics in die-off events of the tropical seagrass, Thalassia testudinum. Journal of Ecology $93,148-158$.

Bos, A., van Katwijk, M.M., 2007. Planting density, hydrodynamic exposure and mussel beds affect survival of transplanted intertidal seagrass. Marine Ecology Progress Series 336, 121-129.

Bostrom, C., Jackson, E.L., Simenstad, C.A., 2006. Seagrass landscapes and their effects on associated fauna: A review. Estuarine Coastal and Shelf Science 68, 383403.

Britto, D.T., Kronzucker, H.J., 2002. NH4+ toxicity in higher plants: a critical review. Journal of Plant Physiology 159, 567-684.

Brun, F., Perez-Llorens, J.L., Hernandez, I., Vergara, J., 2003a. Patch Distribution and WIthin-Patch Dynamics of the seagrass Zostera noltii Hornem. in Los Torunos SaltMarsh, Cádiz Bay, Natural Park, Spain Botanica Marina 46, 513-524.

Brun, F.G., Hernandez, I., Vergara, J.J., Peralta, G., Perez-Llorens, J.L., 2002. Assessing the toxicity of ammonium pulses o the survival and growth of Zostera noltii. Marine Ecology Progress Series 225, 177-187.

Brun, F.G., Perez-Llorens, J.L., Hernandez, I., Vergara, J.J., 2003b. Patch distribution and within-patch dynamics of the seagrass Zostera noltii Hornem. In Los Torunos salt-marsh, Cadiz Bay, Natural Park, Spain. Botanica Marina 46, 513-524.

Burkholder, J.M., Mason, K.M., Glasgow, H.B.J., 1992. Water-column nitrate enrichment promotes decline on eelgrass Zostera marina: evidence from seasonal mesocosm experiments. Marine Ecology Progress Series 81, 163-178. 
Burkholder, J.M., Tomasko, D.A., Touchette, B.W., 2007. Seagrasses and eutrophication. Journal of Experimental Marine Biology and Ecology 350, 46-72.

Calleja, M.L., Marba, N., Duarte, C.M., 2007. The relationship between seagrass (Posidonia oceanica) decline and sulfide porewater concentration in carbonate sediments. Estuarine Coastal and Shelf Science 73, 583-588.

Campbell, M.L., Paling, E.I., 2003. Evaluating vegetative transplant success in Posidonia australis: a field trial with habitat enhancement. Marine Pollution Bulletin $46,828-834$.

Carlson, P.R., Yarbro, L.A., Barber, T.R., 1994. Relationship of sediment sulfide to mortality of Thalassia testudinum in Florida Bay. Bulletin of Marine Science 54, 733746.

Christianen, M.J.A., Govers, L.L., Kiswara, W., Roelofs, J.G.M., Bouma, T.J., Lamers, L.P.M., van Katwijk, M.M., 2012. Marine megaherbivore grazing may increase seagrass resilience to high nutrient loads. Journal of Ecology 100.

Christianen, M.J.A., van der Heide, T., Bouma, T.J., Roelofs, J.G.M., van Katwijk, M.M., Lamers, L.P.M., 2011. Limited toxicity of $\mathrm{NH}(\mathrm{x})$ pulses on an early and late successional tropical seagrass species: Interactions with $\mathrm{pH}$ and light level. Aquatic Toxicology 104, 73-79.

Dean, R.B., Dixon, W.J., 1951. Simplified statistics for small numbers of observations. Analytical Chemistry 23, 636-638.

Di Carlo, G., Kenworthy, W.J., 2008. Evaluation of aboveground and belowground biomass recovery in physically disturbed seagrass beds. Oecologia 158, 285-298.

Duarte, A.C., Fourqurean, J., Krause-Jensen, D., Olesen, B., 2006a. Dynamics of seagrass stability and change, in: Larkum, A.W.D. (Ed.), Seagrasses: Biology, Ecology and Conservation. Springer, The Netherlands, pp. 271-294.

Duarte, C.M., 1990. Seagrass nutrient content. Marine Ecology-Progress Series 67, 201-207.

Duarte, C.M., 2002. The future of seagrass meadows. Environmental Conservation 29, 192-206.

Duarte, C.M., Fourqurean, J.W., Krause-Jensen, D., Olesen, B., 2006b. Dynamics of seagrass stability and change, in: Larkum, A.W.D., Orth, R.J., Duarte, A.C. (Eds.), 
Seagrasses: Biology, Ecology and Conservation. Springer, Dordrecht, The Netherlands.

Duarte, C.M., Sand-Jensen, K., 1990. Seagrass colonization - patch formation and patch growth in Cymodocea nodosa. Marine Ecology-Progress Series 65, 193-200.

Erskine, J.M., Koch, M.S., 2000. Sulfide effects on Thalassia testudinum carbon balance and adenylate energy charge. Aquatic Botany 67, 275-285.

Field, A.P., 2005. Discovering statistics using SPSS, 2nd edition ed. Sage Publications, London.

Fourqurean, J., Zieman, J.C., Powell, G.V.N., 1992. Relationships between porewater nutrients and seagrasses in a subtropical carbonate environment. Marine Biology 114, 57-65.

Frederiksen, M., 2004. Spatial and temporal variation in eelgrass (Zostera marina) landscapes: influence of physical setting. Aquatic Botany 78, 147-165.

Garcia, R., Holmer, M., Duarte, C.M., Marba, N., 2013. Global warming enhances sulphide stress in a key seagrass species (NW Mediterranean). Global Change Biology 19, 3629-3639.

Gray, J.S., Elliott, M., 2009. Ecology of marine sediments. Oxford University Press, New York.

Hauxwell, J., Cebrian, J., Furlong, C., Valiela, I., 2001. Macroalgal Canopies Contribute to Eelgrass (Zostera marina) Decline in Temperate Estuarine Ecosystems. Ecology 82, 1007-1022.

Hemminga, M.A., Duarte, A.C., 2000. Seagrass Ecology. Cambridge University press, Cambridge.

Holmer, M., Bondgaard, E.J., 2001. Photosynthetic and growth response of eelgrass to low oxygen and high sulfide concentrations during hypoxic events. Aquatic Botany 70, 29-38.

Holmer, M., Kendrick, G., 2013. High sulfide intrusion in five temperate seagrass species growing under contrasting sediment conditions. Estuaries and Coasts 36, 116-126.

Holmer, M., Nielsen, S.L., 1997. Sediment sulfur dynamics related to biomass-density patterns in Zostera marina (eelgrass) beds. Marine Ecology-Progress Series 146, 163 171. 
Koch, M.S., Erskine, J.M., 2001. Sulfide as a phytotoxin to the tropical seagrass Thalassia testudinum: interactions with light, salinity and temperature. Journal of Experimental Marine Biology and Ecology 266, 81-95.

Lamers, L.P., Govers, L.L., Janssen, I.C., Geurts, J.J., Van der Welle, M.E., Van Katwijk, M.M., Van der Heide, T., Roelofs, J.G., Smolders, A.J., 2013. Sulfide as a soil phytotoxin - a review. Front Plant Science 4, 268.

Lamers, L.P.M., Tomassen, H.B.M., Roelofs, J.G.M., 1998. Sulfate-induced eutrophication and phytotoxicity in freshwater wetlands. Environmental Science \& Technology 32, 199-205.

Lucassen, E.C.H.E.T., Smolders, A.J.P., van der Salm, A.L., Roelofs, J.G.M., 2004. High groundwater nitrate concentrations inhibit eutrophication of sulfate-rich freshwater wetlands. Biogeochemistry 67, 249-267.

Marba, N., Duarte, C.M., 1998. Rhizome elongation and seagrass clonal growth. Marine Ecology-Progress Series 174, 269-280.

Marba, N., Holmer, M., Gacia, E., Barron, C., 2006. Seagrass beds and coastal biogeochemistry, in: Larkum, A.W.D., Orth, R.J., Duarte, A.C. (Eds.), Seagrasses: Biology, Ecology and Conservation. Springer, Dordrecht, The Netherlands.

Murray, J.W., Grundmanis, V., Smethie, W.M.J., 1978. Interstitial water chemistry in the sediments of Saanich Inlet. Geochimica Et Cosmochimica Acta 42, 1011-1026.

Nienhuis, P.H., Smaal, A.C., 1994. The Oosterschelde estuary, a case-study of a changing ecosystem - An introduction. Hydrobiologia 283, 1-14.

Olesen, B., Sand-Jensen, K., 1994. Patch dynamics of eelgrass Zostera marina. Marine Ecology-Progress Series 106, 147-156.

Orth, R.J., Carruthers, T.J.B., Dennison, W.C., Duarte, C.M., Fourqurean, J.W., Heck, K.L., Hughes, A.R., Kendrick, G.A., Kenworthy, W.J., Olyarnik, S., Short, F.T., Waycott, M., Williams, S.L., 2006. A global crisis for seagrass ecosystems. Bioscience 56, $987-$ 996.

Pages, A., Teasdale, P.R., Robertson, D., Bennett, W.W., Schafer, J., Welsh, D.T., 2012. Representative measurement of two-dimensional reactive phosphate distributions and co-distributed iron(II) and sulfide in seagrass sediment porewaters. Chemosphere 85, 1256-1261. 
Pasqualini, V., Pergent-Martini, C., Pergent, G., 1999. Environmental impact identification along the Corsican coast (Mediterranean sea) using image processing. Aquatic Botany 65, 311-320.

Pedersen, O., Borum, J., Duarte, C.M., Fortes, M.D., 1998. Oxygen dynamics in the rhizosphere of Cymodocea rotundata. Marine Ecology-Progress Series 169, 283-288. Peralta, G., Bouma, T.J., van Soelen, J., Perez-Llorens, J.L., Hernandez, I., 2003. On the use of sediment fertilization for seagrass restoration: a mesocosm study on Zostera marina L. Aquatic Botany 75, 95-110.

Pickett, S.T.A., White, P.S., 1985. The ecology of natural disturbance and patch dynamics. Academic Press, Inc., San Diego, California.

Ruiz-Halpern, S., Macko, S.A., Fourqurean, J.W., 2008. The effects of manipulation of sedimentary iron and organic matter on sediment biogeochemistry and seagrasses in a subtropical carbonate environment. Biogeochemistry 87, 113-126.

Short, F.T., 1983a. The response of interstitial ammonium in eelgrass (Zostera marina L.) beds to environmental pertubations. Journal of Experimental Marine Biology and Ecology 68, 195-208.

Short, F.T., 1983b. The seagrass, Zostera Marina L.: Plant morphology and bed structure in relation to sediment ammonium in izembek lagoon, Alaska. Aquatic Botany 16, 149-161.

Sintes, T., Marba, N., Duarte, C.M., Kendrick, G.A., 2005. Nonlinear processes in seagrass colonisation explained by simple clonal growth rules. Oikos 108, 165-175.

Smolders, A., Roelofs, J.G.M., 1995. Internal eutrophication, iron limitation and sulphide accumulation due to the inlet of rhiver Rhine water in peaty shallow waters in the Netherlands. Archiv Fur Hydrobiologie 133, 349-365.

Smolders, A.J.P., Moonen, M., Zwaga, K., Lucassen, E., Lamers, L.P.M., Roelofs, J.G.M., 2006. Changes in pore water chemistry of desiccating freshwater sediments with different sulphur contents. Geoderma 132, 372-383.

Terrados, J., Duarte, C.M., Kamp-Nielsen, L., Agawin, N.S.R., Gacia, E., Lacap, D., Fortes, M.D., Borum, J., Lubanski, M., Greve, T., 1999. Are seagrass growth and survival constrained by the reducing conditions of the sediment? Aquatic Botany 65, 175-197. 
Thursby, G.B., Harlin, M.M., 1982. Leaf-root interaction in the uptake of ammonia by Zostera marina. Marine Biology 72, 109-112.

Toetz, D.W., 1973. The Kinetics of NH4 uptake by Ceratophylum. Hydrobiologia 41, 275-290.

Touchette, B., Burkholder, J.M., Glasgow, H.B., 2003. Variations in eelgrass (Zostera marina L.) morphology and internal nutrient composition as influenced by increased temperature and watercolumn nitrate. Estuaries 26, 142-155.

Touchette, B.W., Burkholder, J.M., 2000. Review of nitrogen and phosphorus metabolism in seagrasses. Journal of Experimental Marine Biology and Ecology 250, 133-167.

Townsend, E.C., Fonseca, M.S., 1998. Bioturbation as a potential mechanism influencing spatial heterogeneity of North Carolina seagrass beds. Marine EcologyProgress Series 169, 123-132.

Troost, K., Gelderman, E., Kamermans, P., Smaal, A.C., Wolff, W.J., 2009. Effects of an increasing filter feeder stock on larval abundance in the Oosterschelde estuary (SW Netherlands). J. Sea Res. 61, 153-164.

Turner, M.G., Gardner, R.H., O'Neil, R.V., 2001. Landscape Ecology in Theory and Practise: Pattern and Process. Springer-Verlag, New York.

Van der Heide, T., 2009. Stressors and feedbacks in temperate seagrass ecosystems, PhD thesis. Radboud University Nijmegen.

Van der Heide, T., Bouma, T.J., Van Nes, E.H., Van de Koppel, J., Scheffer, M., Roelofs, J.G.M., Van Katwijk, M.M., Smolders, A.J.P., 2010a. Spatial self-organized patterning in seagrasses along a depth gradient of an intertidal ecosystem. Ecology 91, 362-369. Van der Heide, T., Govers, L.L., de Fouw, J., Olff, H., van der Geest, M., van Katwijk, M.M., Piersma, T., van de Koppel, J., Silliman, B.R., Smolders, A.J.P., van Gils, J.A., 2012. A three-stage symbiosis forms the foundation of seagrass ecosystems. Science $336,1432-1434$.

Van der Heide, T., Smolders, A., Rijkens, B., Van Nes, E.H., Van Katwijk, M.M., Roelofs, J., 2008. Toxicity of reduced nitrogen in eelgrass (Zostera marina) is highly dependent on shoot density and pH. Oecologia 158, 411-419. 
Van der Heide, T., Van Nes, E.H., Van Katwijk, M.M., Scheffer, M., Hendriks, A.J., Smolders, A.J.P., 2010b. Alternative Stable States Driven by Density-Dependent Toxicity. Ecosystems 13, 841-850.

van Katwijk, M.M., Vergeer, L.H.T., Schmitz, G.H.W., Roelofs, J.G.M., 1997. Ammonium toxicity in eelgrass Zostera marina. Marine Ecology Progress Series 157, 159-173.

Vanlent, F., Verschuure, J.M., Vanveghel, M.L.J., 1995. Comparative study on populations of Zostera marina L (eelgrass) - in situ nitrogen enrichment and light manipulation. Journal of Experimental Marine Biology and Ecology 185, 55-76.

Vermaat, J.E., 2009. Linking clonal growth patterns and ecophysiology allows the prediction of meadow-scale dynamics of seagrass beds. Perspectives in Plant Ecology Evolution and Systematics 11, 137-155.

Vidondo, B., Duarte, C.M., Middelboe, A.L., Stefansen, K., Lutzen, T., Nielsen, S.L., 1997. Dynamics of a landscape mosaic: size and age distributions, growth and demography of seagrass Cymodocea nodosa patches. Marine Ecology-Progress Series 158, 131-138.

Waycott, M., Duarte, C.M., Carruthers, T.J.B., Orth, R.J., Dennison, W.C., Olyarnik, S., Calladine, A., Fourqurean, J.W., Heck, K.L., Hughes, A.R., Kendrick, G.A., Kenworthy, W.J., Short, F.T., Williams, S.L., 2009. Accelerating loss of seagrasses across the globe threatens coastal ecosystems. Proceedings of the National Academy of Sciences 106, 12377-12381.

Wood, E.D., Armstron.Fa, Richards, F.A., 1967. Determination of nitrate in sea water by Cadmium-Copper reduction to nitrite. Journal of the Marine Biological Association of the United Kingdom 47, 23-\&. 
Table 1. Results of 2 -way ANOVAs (NPK * OM) for all shown variables of Zostera noltii after 77 days. $* 0.01 \leq p \leq 0.05 . * * 0.001 \leq p \leq 0.01 . * * * p$ $\leq 0.001$. ns $=$ not significant.

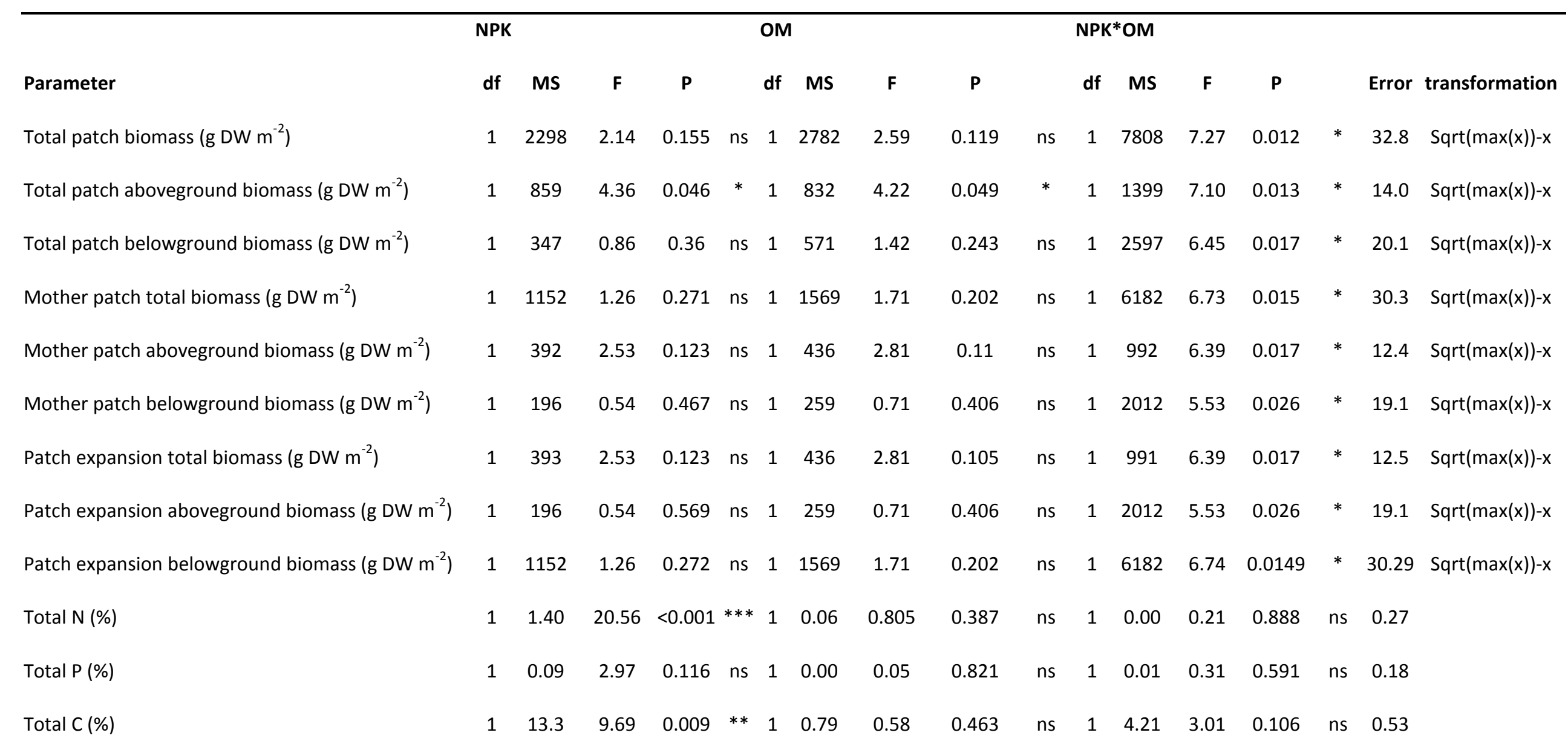


Total S (\%)

$\mathrm{C}: \mathrm{N}$ (molar ratio)

$\mathrm{N}: \mathrm{P}$ (molar ratio) $\begin{array}{llllllll}1 & 4.87 & 8.15 & 0.015 & * & 1 & 0.92 & 1.55\end{array}$

$\begin{array}{llllllll}1 & 52.8 & 12.78 & 0.005 & * * & 1 & 0.38 & 0.09\end{array}$
0.410

$\begin{array}{lllll}\text { ns } & 1 & 0.01 & 0.27 & 0.613\end{array}$

0.237

ns

0.767

ns $\quad 1 \quad 1.28$

$0.63 \quad 0.443$

ns $\quad 0.77$

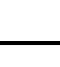


Table 2. Results of the 3-way (time*NPK*OM) repeated measures ANOVAs $\left(t_{0}, t_{21}, t_{49}, t_{77}\right)$ for shoot densities $\left(m^{-2}\right)$ and all relevant porewater nutrients. $\mathrm{F}$ values and significance levels are shown for all the main effects and interactions $* 0.01 \leq P \leq 0.05 .{ }^{* *} 0.001 \leq P \leq 0.01 .{ }^{* * *} P \leq$ 0.001. ns = not significant. $\mathrm{df}$ stands for adjusted degrees of freedom as a result of the Greenhouse-Geisser correction for violated sphericity..

\begin{tabular}{|c|c|c|c|c|c|c|c|c|c|c|c|c|c|c|c|c|}
\hline & \multicolumn{4}{|c|}{ Time } & \multicolumn{4}{|c|}{ Time*NPK } & \multicolumn{4}{|c|}{ Time*OM } & \multicolumn{4}{|c|}{ Time*NPK*OM } \\
\hline & df & $\mathbf{F}$ & $P$ & & df & $\mathbf{F}$ & $P$ & & df & $\mathbf{F}$ & $P$ & & df & $\mathbf{F}$ & $P$ & \\
\hline Shoots mother patch (shoots $\mathrm{m}^{-2}$ ) & 1.4 & 5.623 & 0.009 & $* *$ & 1.1 & 1.88 & 0.226 & ns & 1.2 & 1.666 & 0.252 & ns & 1.1 & 7.429 & 0.034 & $*$ \\
\hline Shoots patch expansion (shoots $\mathrm{m}^{-2}$ ) & 1.1 & 5.884 & 0.041 & $*$ & 1.1 & 2.098 & 0.189 & ns & 1.2 & 1.735 & 0.227 & ns & 1.1 & 0.733 & 0.435 & ns \\
\hline Sulfide $\left(\mu \mathrm{mol} \mathrm{L}{ }^{-1}\right)$ & 1.2 & 9.100 & 0.019 & $*$ & 1.2 & 7.709 & 0.023 & $*$ & 1.4 & 6.047 & 0.007 & $* *$ & 1.3 & 5.882 & 0.007 & $* *$ \\
\hline Ammonium $\left(\mu \mathrm{mol} \mathrm{L}^{-1}\right)$ & 1.8 & 7.683 & 0.007 & $* *$ & 1.8 & 5.870 & 0.004 & $* *$ & 1.3 & 0.956 & 0.390 & ns & 1.6 & 0.662 & 0.501 & ns \\
\hline Nitrate $\left(\mu \mathrm{mol} \mathrm{L}^{-1}\right)$ & 1.5 & 5.070 & 0.034 & $*$ & 1.5 & 4.678 & 0.038 & $*$ & 1.3 & 1.326 & 0.295 & ns & 1.6 & 1.215 & 0.322 & ns \\
\hline Phosphate $\left(\mu \mathrm{mol} \mathrm{L}^{-1}\right)$ & 2.1 & 13.569 & 0.000 & $* * *$ & 1.7 & 5.418 & 0.026 & $*$ & 1.2 & 1.754 & 0.225 & ns & 3.0 & 0.701 & 0.562 & ns \\
\hline
\end{tabular}


Table 3. Elemental composition of the leaves. Molar C:N:P ratios and percentages $\left(\mathrm{g}^{-1}\right)$ of leaf tissue nutrients.

\begin{tabular}{lrrrrr}
\hline Treatment & C:N:P & $\% \mathbf{C}$ & $\% \mathbf{N}$ & $\% \mathbf{P}$ & $\% \mathrm{~S}$ \\
Control & $121: 10: 01$ & 39.3 & 3.83 & 0.89 & 1.77 \\
NPK & $161: 15: 01$ & 40.3 & $4.40 \mathrm{a}$ & 0.65 & 1.11 \\
NPK+OM & $140: 14: 01$ & 41.3 & 4.56 & 0.75 & 1.11 \\
OM & $114: 10: 01$ & 38.0 & 3.94 & 0.87 & 1.66 \\
\hline
\end{tabular}




\section{Figure legends}

Figure 1. Porewater concentrations of sulfide (a), phosphate (b), ammonium (c) and nitrate

(d) during the experiment. Error bars represent SEM ( $n=8)$.

Figure 2. Aboveground (a) and belowground biomass (b) of patch expansion (dashed bars) and mother patch (straight line); dashed lines indicate initial aboveground and belowground biomasses. Error bars represent SEM of total aboveground and belowground biomass, $\mathrm{n}=8$.

Figure 3 Shoot densities of the mother patch (a) and in the expansion area (b) in time; error bars represent $\mathrm{SEM}, \mathrm{n}=8$.

Figure 4. Scatterplots of mother patch biomass and weighted average porewater sulfide concentrations (a) and ammonium concentrations (b), and expansion biomass and weighted average porewater sulfide concentrations (c) and ammonium concentrations (d) with exponential regression lines and related $R^{2}$ values. 

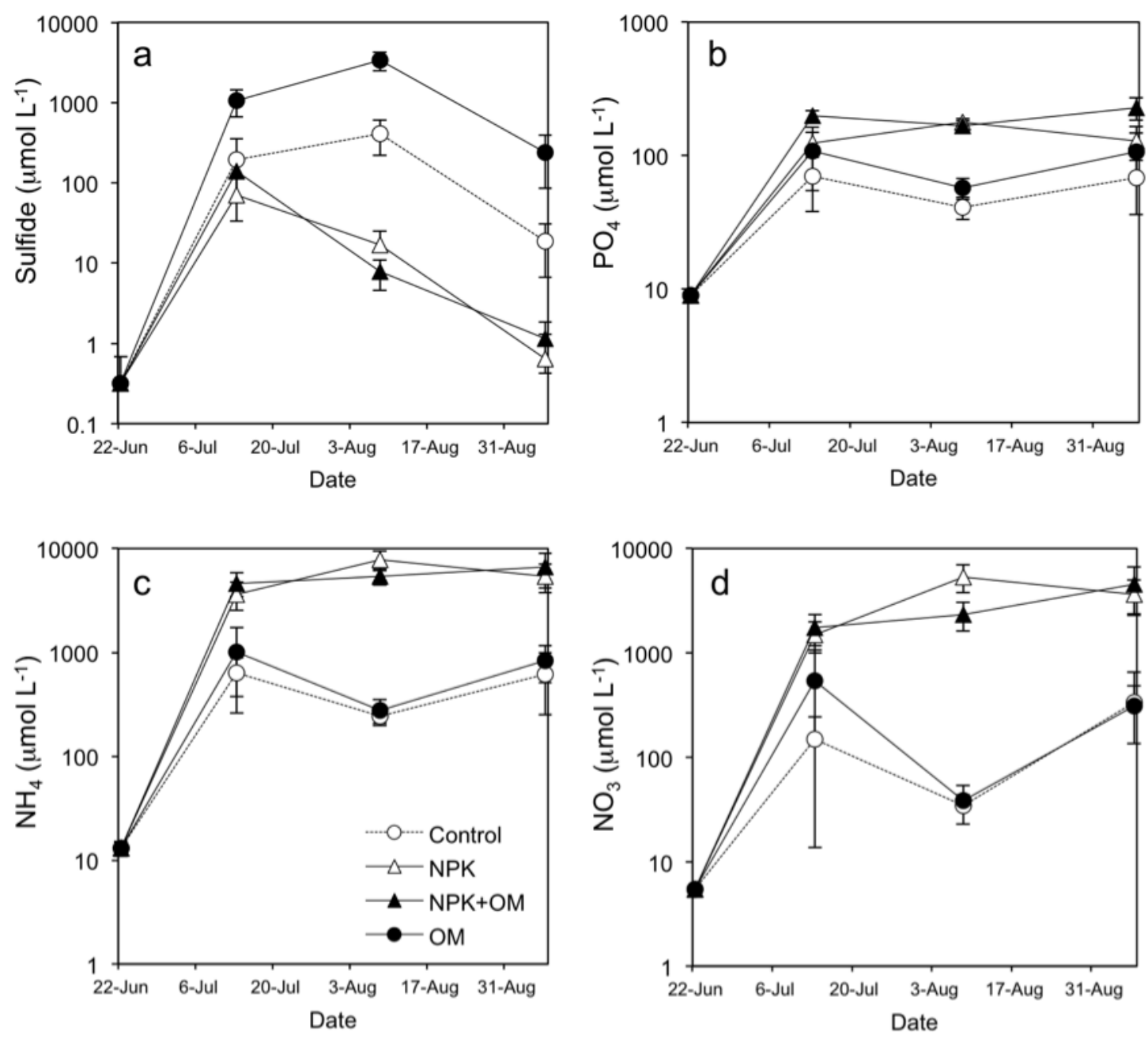

Figure 1 


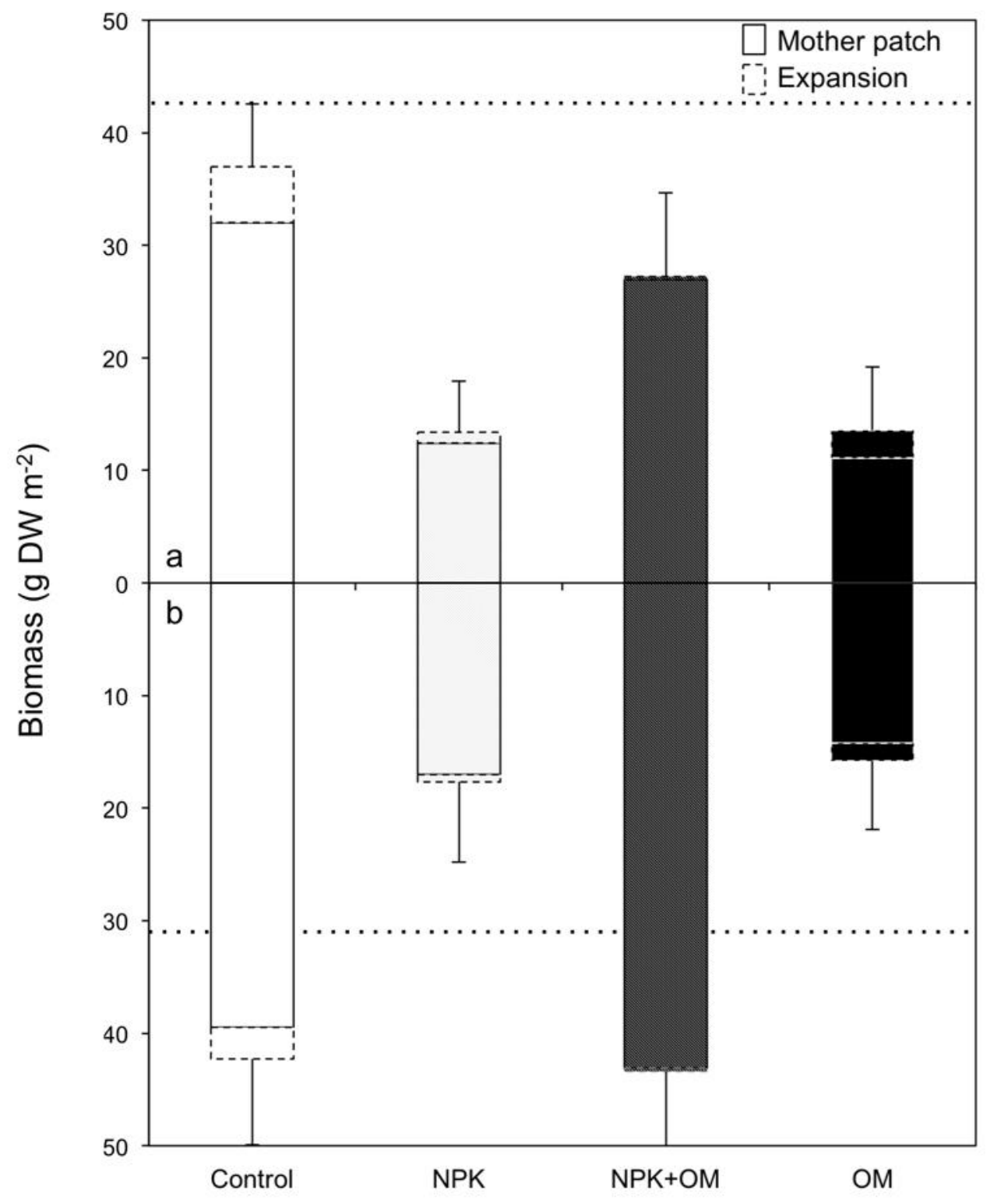

Figure 2 

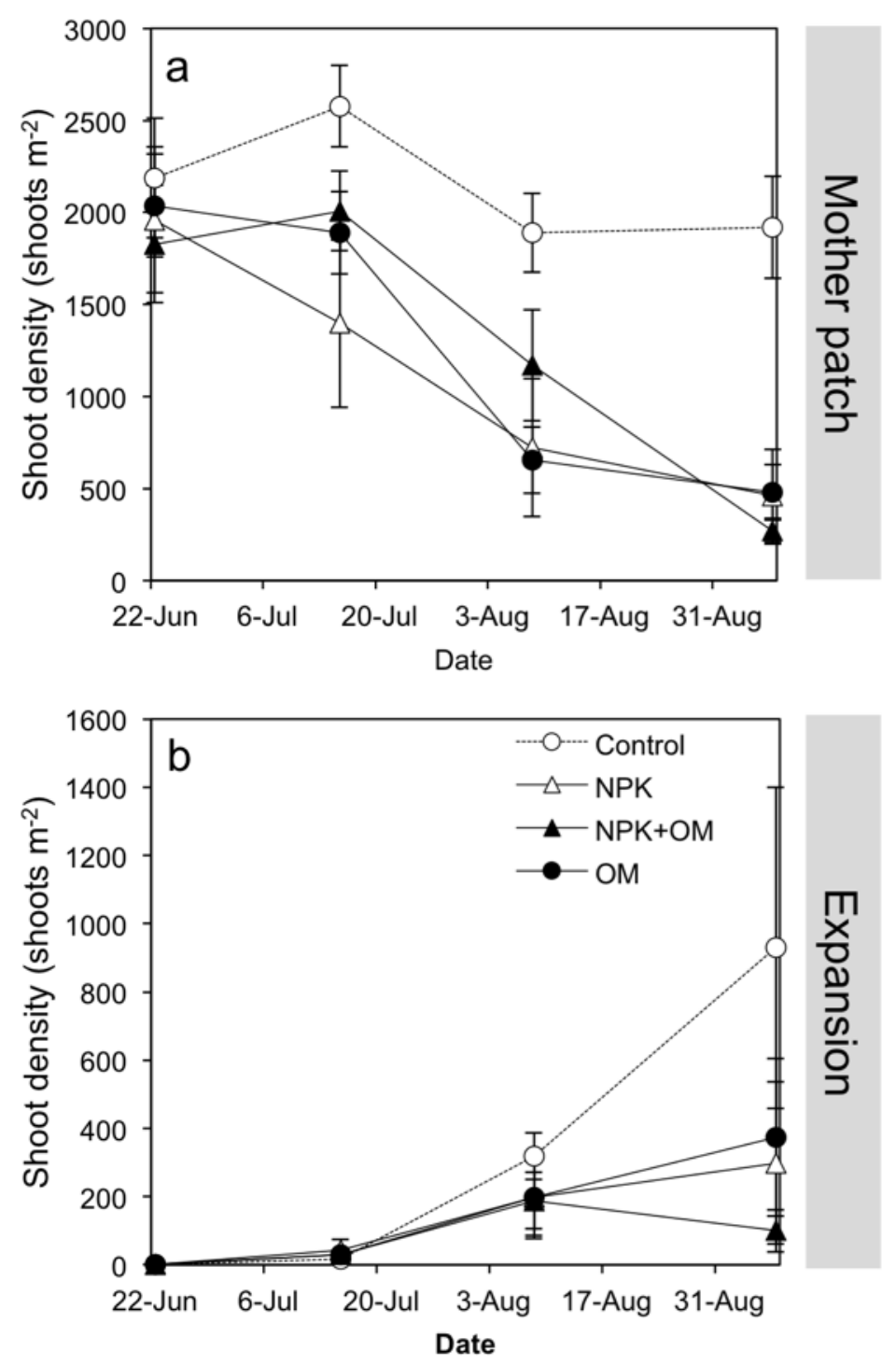

Figure 3 

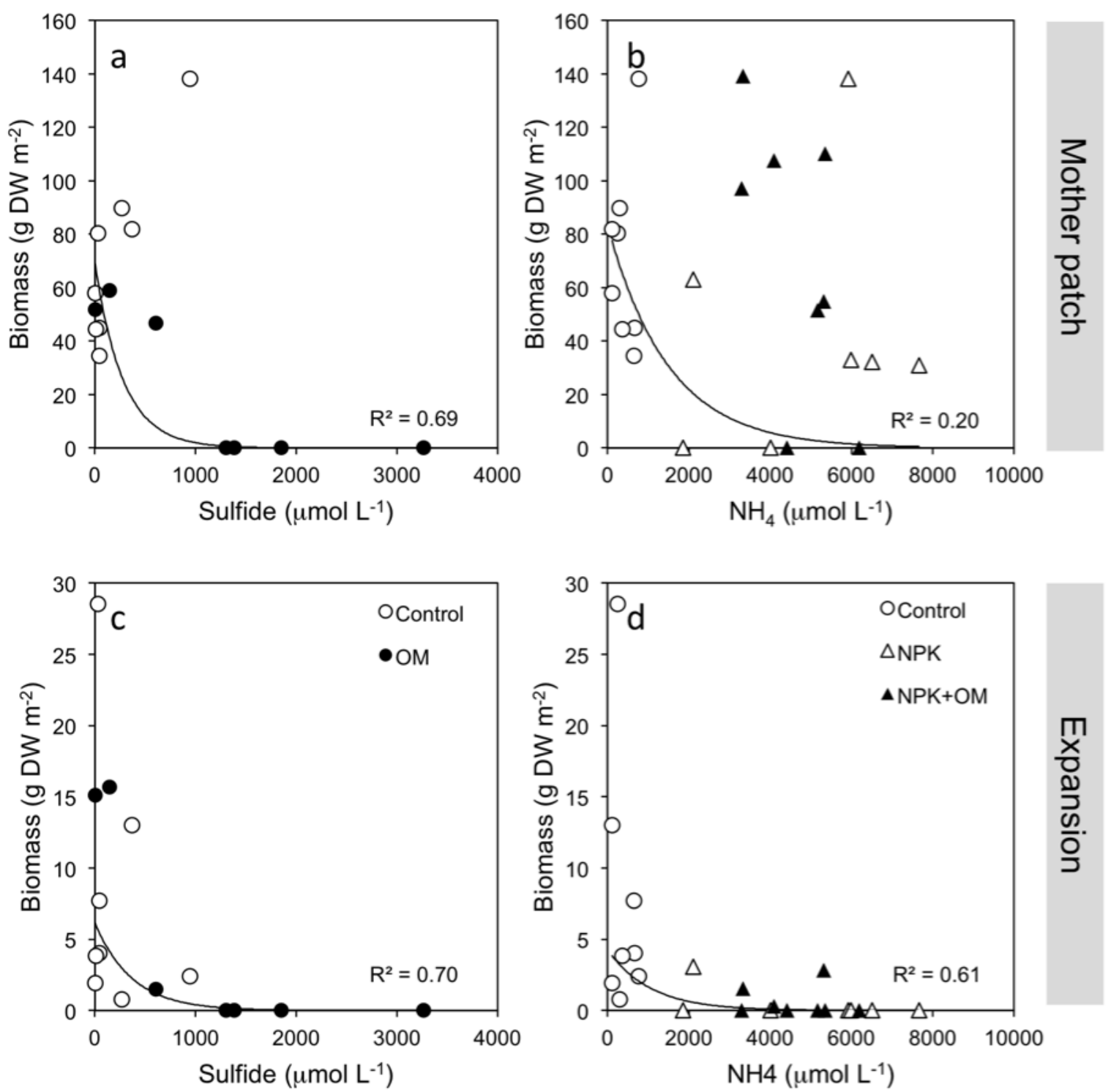

Figure 4 